\title{
Egypt: Encourage journalists to cover reproductive health
}

Frontiers in Reproductive Health

Follow this and additional works at: https://knowledgecommons.popcouncil.org/departments_sbsr-rh

Part of the Journalism Studies Commons, Public Health Education and Promotion Commons, and the Technical and Professional Writing Commons

How does access to this work benefit you? Let us know!

\section{Recommended Citation}

"Egypt: Encourage journalists to cover reproductive health," FRONTIERS OR Summary. Washington, DC: Population Council, 2000. 


\section{Egypt \\ Dissemination}

OR Summary 15

\section{Encourage Journalists to Cover Reproductive Health}

After Egyptian print journalists attended a series of briefings on reproductive health issues, their reporting of these issues improved. Health agencies can improve coverage of reproductive health issues by providing a regular flow of accurate information to a broad range of journalists.

\section{Background}

To raise public awareness of reproductive health $(\mathrm{RH})$ issues, the Population Council FRONTIERS project and the Futures Group POLICY project jointly organized press briefings and provided background materials to key journalists from Arabic newspapers and magazines. From May 1999 to June 2000, project staff worked closely with 20 Egyptian journalists, including editors of women's pages and senior editors. The four press briefings covered youth, marriage patterns, contraceptive technology, and menopause. The press kit prepared for each briefing contained fact sheets, reference materials, a contact list of key experts, and an evaluation sheet.

To assess RH reporting and track coverage resulting from the intervention, project staff monitored eight major Arabic newspapers and nine magazines daily. All articles on RH were coded according to their topic, length, and use of research findings.

\section{Findings}

- The press briefings did generate press coverage. Of the $433 \mathrm{RH}$ articles published in newspapers from May 1999 through March 2000, one-fifth covered topics featured in the press briefings. Similarly, onethird of the 127 magazine articles identified covered press briefing topics.

"The numbers and figures presented ... will have a more effective impact on public opinion." -Participating journalist

- Journalists attending the press briefings reported that their knowledge of RH issues increased and that they planned to use the press kits to write their articles. Some journalists shared the press kits with their colleagues.

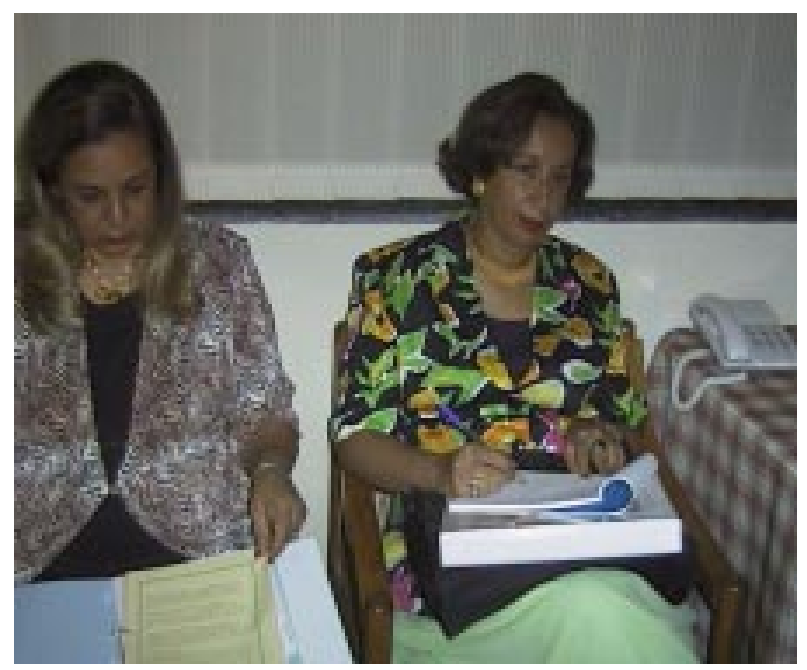


- The project did improve the quality of reporting, but room for further improvement remains. Roughly one in three articles based on the press briefings cited research findings or information included in the press kit. Although project staff stressed the need to use multiple sources, most articles were based on a single source of information.

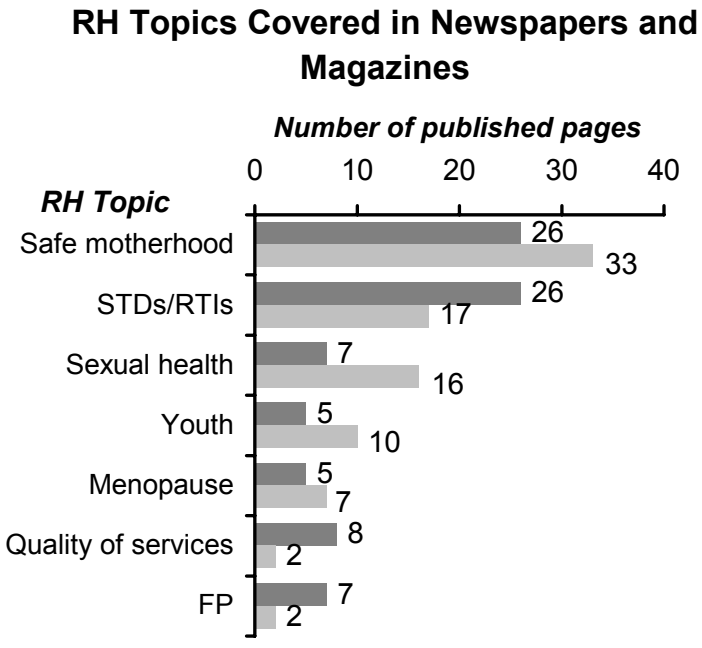

Newspapers Magazines

- Of the total pages devoted to RH topics, more than one in four dealt with safe motherhood. The second most popular topic was reproductive tract infections, followed by sexual health, youth, menopause, and quality of services (see Figure).

- The majority of RH newspaper articles were news stories. In contrast, more than half of the magazine articles were feature stories; half of these articles were one page or longer. Both media formats are useful for research dissemination: newspapers are widely read by policymakers, while magazines tend to be shared with others and retained for a long time.

\section{Policy Implications}

- Research dissemination should include briefings and resource materials for journalists. Links with both print and broadcast journalists should be developed.

- To broaden the range of RH topics presented, more local agencies should be involved in media relations activities. More information about family planning and female genital cutting* should be provided to journalists, since these topics currently receive little press coverage.

- Health agencies should seek to improve the quality of reporting by providing a regular flow of accurate information and helping journalists to identify newsworthy stories.

*See OR Summary 14, NGOs Need to Join Forces to End FGC.

Hegazi, Sahar and Mona Khalifa. 2000. Increasing the Coverage of Reproductive Health Issues in the Egyptian Press: Final Report. For more information or to obtain a copy of the English Final Report of this study, contact: Population Council, 6A Giza St.,P.O. Box 115, Dokki 12211, Giza, Cairo, Egypt.Tel.: 20-2-5725910; Fax: 20-2-5701804; E-mail: frontiers@pccairo.org .

This project was conducted with support from the U.S. AGENCY FOR INTERNATIONAL DEVELOPMENT under Cooperative Agreement Number HRN-A-00-98-00012-00. 